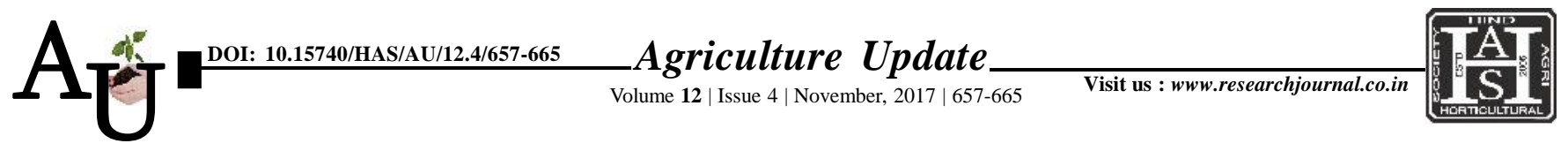

口 e ISSN-0976-6847

\title{
Research Article: Recent advances in the production of pomegranate fruit crop
}

\section{MADHURI SHRIKANT SONAWANE}

\section{Article Chronicle :} Received :

14.09.2017;

Revised :

23.09.2017;

Accepted :

10.10.2017

\section{KeY WoRDS :}

Pomegranate, Planting systems, Crop regulation, Training, Pruning
SUMMARY : India is the world's largest producer of pomegranates produced over 1.31 lakh ha area with an annual production of 13.46 lakh tonnes and productivity of $10.27 \mathrm{t} / \mathrm{ha}$. In spite of this, India exports only $2.55 \%$ of its total production. There is a tremendous potential for exports of pomegranate from India. In India, Maharashtra is the main pomegranate producing state. It observed decreasing trend in area, production and productivity since 2009-10 owing to mainly the oily spot infestation and various other reasons. Since 2012-13, an increasing trend is witnessed. In the present study, efforts have been made to present and discuss recent technologies followed in the production of pomegranate fruit crop, various concepts and techniques of growing the pomegranate fruit crop i.e. propagation methods, planting systems, flowering and fruiting aspects of crop regulation, training and pruning, stress factors and their management, water and nutrient management, total quality management, etc.

How to cite this article : Sonawane, Madhuri Shrikant (2017). Recent advances in the production of pomegranate fruit crop. Agric. Update, 12(4): 657-665; DOI : 10.15740/HAS/AU/12.4/657-665.
Author for correspondence : MADHURI SHRIKANT SONAWANE

School of Agricultural Sciences, Yashwantrao Chavan Maharashtra Open University, NASHIK (M.S.) INDIA 